\title{
On the role of interdisciplinary, transdiscliprinary, and philosophical knowledge in modern higher education
}

\author{
Zoya D. Denikina ${ }^{{ }^{*}}$ and Anatoly $V$. Denikin ${ }^{1}$ \\ ${ }^{1}$ Financial University, Department of Humanities, Moscow, Russia
}

\begin{abstract}
The article traces the substantial and functional evolution of interdisciplinary and transdisciplinary knowledge and its integration into the theory and practice of higher education. The method of distinguishing between classical, non-classical, and post-non-classical rationality is used to disclose the specifics of university transdisciplinarity. The proposed hypothesis suggests that in non-classical and post-non-classical education, different types of studied objectivity exist while when the subject boundaries are fixed, various forms of subject uncertainty are observed. Difficulties in the practice of non-classical education are associated with the objective of overcoming double uncertainty. In one case, the onedimensionality of the study depends on the choice of ontological conditions that are only sufficient for a given monodiscipline. In another case, the task of combining the intervals of studying a subject in the framework of multidisciplinary knowledge is being solved. Transdisciplinarity manifests primarily through educational modeling technologies. What can be attributed to the specifics of post-non-classical education is the study of two types of objectivity: the system-level reality in cases of severe disequilibrium and the system-operational reality in cases of mild disequilibrium. Thus, the subject area demonstrates substantial and systemic uncertainty. It is concluded that the study of systemic objects as a part of the educational process requires interdisciplinary efforts and is carried out in line with the following scheme: problem - project - concept - practical solution.
\end{abstract}

Keywords: transdisciplinarity in non-classical education, transdisciplinarity in post-non-classical education, subject uncertainty.

\section{Introduction}

The topic of transdisciplinarity is directly related to the development trends of modern science and education [1-3]. This term was first used by J. Piaget in 1970 to refer to the principle of scientific study. In 1980, E. Jantsch defined transdisciplinarity as an integral principle of disciplinary knowledge aggregating the achievements of science, education, and innovation [4]. In 1987, an international center for transdisciplinary research was formed [5], and in 1994, at the 1st World Congress on Transdisciplinarity, the

\footnotetext{
* Corresponding author: zooden@mail.ru
} 
corresponding Charter was adopted. The proposed summaries distinguish between interdisciplinarity and transdisciplinarity. In the case of the first term, disciplinary goals are retained but the methods of one discipline are transferred to another. As for the second concept, transdisciplinary knowledge is localized between disciplines, beyond the boundaries of individual ones. The phenomenon of transdisciplinarity is also of considerable interest in Russian science [6-9].

\section{Methods}

The state of interdisciplinary and transdisciplinary knowledge is most certainly considered when determining the specifics of the Russian philosophy of science. We will utilize a reverse methodological method and attempt to trace the dynamics of these types of knowledge relying on the general philosophical and scientific positions. In particular, we will use the scheme for distinguishing between classical, non-classical, and post-nonclassical scientific rationality proposed by an academic V. Stepin [10]. Non-classical and post-non-classical education will be examined by analogy with the same demarcation. Modern science also deals with "Science 2.0" (M. Gibbons, H. Nowotny) or post-academic science (J. Ziman).

\section{Results and discussion}

In the Russian Federation, non-classical education peaked in the 1990s. It involves multidisciplinary thinking while educational practice welcomes polymethodological nuances which only present a problem for transdisciplinary knowledge. Conceptual and ontological ambiguity of the object of study is considered an acceptable abstraction in teaching methodology. When the subject boundaries are fixed, a teacher faces the phenomenon of double uncertainty. The monodiscipline being taught sets an interval of ontological conditions for the existence of the object which inevitably leads to a one-sided understanding of it. On the other hand, a monodiscipline occupies a certain place in the scope of multidisciplinary and interdisciplinary knowledge. A teacher has to account for the multidimensionality of the studied object the parameters of which are sufficient only for the given set of conditions.

Multidisciplinary knowledge conjugates intervals of study according to the principle of additionality, that is, each interval potentially implies the presence of other conditions of object existence. A teacher is forced to consider subject mobility and to predict the range of possible ontological conditions affecting the object characteristics. The pedagogical practice of non-classical education explicitly and implicitly involves the competency of presenting multidimentional objectivity. One of the educational objectives lies in mastering the method of modeling [11]. Models synthesize objectivity and the conditions of its existence, eliminates uncertainty, and sets boundaries for explanations and interpretations. In this case, transdisciplinary knowledge (philosophical and general scientific foundations) performs the structuring function according to the following scheme: object - concept 1 model 1 - concept 2 , object - concept 2 - model 2 - concept 3 , and so on. The created models are proportional to each other and, despite the alternative ontological conditions, the object under study is being assembled [12].

What is then the role of philosophy in the development of non-classical education? Ultimately, philosophy and the humanities contribute to the discovery of the uniformity of ontological, epistemological, and axiological foundations of scientific research programs. On the other hand, heterogeneous monodisciplinary content becomes a form of 
manifestation of homogeneous objectivity created from a plurality of conditions and multidimensional properties.

We believe that the identification of the foundations and the allocation of the initial transdisciplinary unity are directly linked to determining the limits of the corresponding research program. Within each paradigm, research programs and disparate concepts gain the ability to be integrated into transdisciplinary knowledge.

Let us refer to the emerging trends in the development of post-non-classical education. The current agenda focuses on interdisciplinary scientific knowledge and its epistemological results while the applied methodology often appears as a way of constructing ontological constants [12]. The studied objects are supercomplex and conceptual uncertainty in most cases arises when understanding the interaction of the object of a system and the external environment [13]. Post-non-classical science is ultimately concerned with two types of ontological objectivity: 1) the system-level reality (for the states of severe disequilibrium) and 2) the systemic-operational reality (for the states of mild disequilibrium).

Of relevance in this context is, on the one hand, the study of the processes of the selforganization of chaos into order, while on the other hand, it is the study of selfreproduction, maintaining the systemic order. Systemic chaos marks the structural anomalies leading to intrinsic uncertainty. In another case, a disruption in autopoiesis may be associated with ineffective system decisions and operations which then entails systemic uncertainty.

Interdisciplinary knowledge of post-nonclassical science works in both of these and serves as their conceptual and methodological justification [14]. To the attention of postnon-classical education come not only these two types of objectivity but also the conceptual uncertainties associated with them which create difficulties in practical teaching. Any studied object determined by a situation of severe disequilibrium contains the elements of the chaos of the previous and the future order. At the same time, the studied object is embedded into the framework of systemic changes, and explaining it outside of this framework is an unproductive cognitive procedure [15]. Interpreting such systemic objects calls for interdisciplinary efforts in the educational process and can be carried out following the scheme: problem - project - concept - practical solution. In the case of an autopoietic object, the consideration algorithm shifts from a synergistic methodology to a systemic interpretation of sustainable development.

\section{Conclusion}

Post-non-classical education is problematic in its very essence [16]. A teacher uses interdisciplinary resources to determine the systemic nature of the problems. For this reason, the objective of identifying such problems comes into the foreground. Uncertainties in conceptualization and, therefore, difficulties in teaching are explained by the attempt to reduce the supercomplex systemic reality in its interaction with the outside world. A teacher should bear in mind that any information, operation, or event cannot be presented in a nominalistic way as they are initially systemic. In this case, the role of philosophy lies in creating a transdisciplinary solution to this problem. The project form of education is becoming embedded into the process of mastering educational standards, as well as intersubjective discourses. Projects are multi-vector and constructive and have a pronounced pragmatic context.

We should emphasize that in conceptualizing the problem of a project, the interaction of classical, non-classical, and post-non-classical philosophical and scientific paradigms is the most effective. The specifics of post-non-classical transdisciplinarity lies in the active search for the inter-paradigm ways of presenting systemic reality. Supercomplex objects in 
a state of relative order can be adequately described by classical concepts. Gnoseological reconstruction of the periods outside the state of chaos is based on the conceptual apparatus of non-classical and post-non-classical science. In a practical sense, a student learns about the ontological and conceptual history of the studied object. The utilized paradigms are not mere abstractions but methodological tools for constructing the educational process [17]. The epistemological results of modern philosophy of science used in modern education contribute to the elimination of theoretical and methodological gaps and link together the ontological and epistemological fragments of paradigms.

\section{Acknowledgments}

The article was prepared based on the results of studies carried out at the expense of the scientific fund of the Financial University.

\section{References}

1. N.M. Smirnova (Ed.), Intersubyektivnost' v nauke i filosofii [Intersubjectivity in science and philosophy] (Kanon, Moscow, 2014)

2. A.N. Pavlenko, Predely intersubyektivnosti (kritika kommunikativnoy sposobnosti znaniya) [Limits of intersubjectivity (criticism of the communicative ability of knowledge)] (Aleteya, Saint Petersburg, 2013)

3. G. Sorkos, C. Hajisoteriou, Pedagogy, Culture \& Society (to be published). https://doi.org/10.1080/14681366.2020.1765193

4. E. Jantsch, The self-organizing Universe. Scientific and human implications of the emerging paradigm of evolution (Pergamon, New York, 1980)

5. R. Volckmann, Integral Review, 4, 73-90 (2007). Accessed on: December 08, 2020. [Online]. Available: https://integralreview.org/issues/issue_4_volckmann_nicolescu_interview.pdf

6. I.T. Kasavin, Mezhdistsiplinarnost' v naukakh i filosofii [Interdisciplinarity in sciences and philosophy] (Russian Academy of Sciences Institute of Philosophy, Moscow, 2010). Accessed on: December 08, 2020. [Online]. Available: https://iphras.ru/uplfile/root/biblio/2010/Mezhdis_Kasavin

7. L.P. Kiyashchenko, Filosofiya transdistsiplinarnosti [Philosophy of transdisciplinarity] (Russian Academy of Sciences, Moscow, 2009)

8. V.N. Porus, Epistemologiya \& Filosofiya Nauki, 2 (2005)

9. S.M. Piastolov, Terra Economius, 14(2), 139-158 (2016). https://doi.org/10.18522/2073-6606-2016-14-2-139-158

10. V.S. Stepin, Teoreticheskoye znaniye : struktura, istoricheskaya evolyutsiya [Theoretical knowledge: structure, historical evolution] (Progress-Traditsiya, Pik Viviti, Liubertsy, 2003)

11. L. Keviczky, C. Bányász, Universal Journal of Educational Research, 5(12), 21962208 (2017). https://doi.org/10.13189/ujer. 2017.051209

12. A.V. Denikin, Z.D. Denikina, Sotsiologiya v poiskakh ontologii [Sociology in search of ontology], in Stolknoveniye vs sblizheniye tsivilizatsiy [Collision vs rapprochement of civilizations] (Otechestvo, Kazan, 2020)

13. C. Pohl, G. Hadorn, Principles for designing transdisciplinary research - proposed by the Swiss Academies of Arts and Sciences (Oekom Verlag, München, 2007) 
14. V.N. Gulyaev, Postneklassicheskiy etap razvitiya didaktiki vysshey shkoly [Postnonclassical stage in the development of higher education didactics], in Psikhologiya I pedagogika 21veka: teoriya, praktika I perspektivy [Psychology and pedagogy of $21 \mathrm{st}$ century: theory, practice and perspectives] (Peoples friendship University, Moscow, 2015)

15. S.Yu. Rzheutskaia, M.V. Kharina, Otkrytoye Obrazovaniye, 21(2), 21-28 (2017). https://doi.org/10.21686/1818-4243-2017-2-21-28

16. R.N. Gorana, P.R. Kanaujia (Eds.), A New Paradigm of Education Towards Sustainable Development, in Reorienting Educational Efforts for Sustainable Development (Springer Netherlands, Heidelberg, 2016)

17. O. Bayraktar, M.A. Dombayci, International Journal of Progressive Education, 16(6), 245-272 (2020). https://doi.org/10.29329/ijpe.2020.280.15

18. A.V. Denikin, Rol' informatsionnykh i pedagogicheskikh tekhnologiy v formirovanii sotsial'nogo kapitala [The role of information and pedagogical technologies in the formation of social capital], in Proceedings of The Forth International Financial University Forum Growth or Recession: Which to Expect?, 28-29 November 2017, Moscow, Russia (2018) 